\title{
Sexually Transmitted Infection and Chemsex Also Highly Prevalent Among Male Sex Workers Outside Amsterdam, The Netherlands
}

Citation for published version (APA):

Peters, C. M. M., Evers, Y. J., Dukers-Muijrers, N. H. T. M., \& Hoebe, C. J. P. A. (2020). Sexually

Transmitted Infection and Chemsex Also Highly Prevalent Among Male Sex Workers Outside Amsterdam, The Netherlands. Sexually Transmitted Diseases, 47(6), E15-E15.

https://doi.org/10.1097/OLQ.0000000000001174

Document status and date:

Published: 01/06/2020

DOI:

10.1097/OLQ.0000000000001174

Document Version:

Publisher's PDF, also known as Version of record

\section{Document license:}

Taverne

Please check the document version of this publication:

- A submitted manuscript is the version of the article upon submission and before peer-review. There can be important differences between the submitted version and the official published version of record.

People interested in the research are advised to contact the author for the final version of the publication, or visit the DOI to the publisher's website.

- The final author version and the galley proof are versions of the publication after peer review.

- The final published version features the final layout of the paper including the volume, issue and page numbers.

Link to publication

\footnotetext{
General rights rights.

- You may freely distribute the URL identifying the publication in the public portal. please follow below link for the End User Agreement:

www.umlib.nl/taverne-license

Take down policy

If you believe that this document breaches copyright please contact us at:

repository@maastrichtuniversity.nl

providing details and we will investigate your claim.
}

Copyright and moral rights for the publications made accessible in the public portal are retained by the authors and/or other copyright owners and it is a condition of accessing publications that users recognise and abide by the legal requirements associated with these

- Users may download and print one copy of any publication from the public portal for the purpose of private study or research.

- You may not further distribute the material or use it for any profit-making activity or commercial gain

If the publication is distributed under the terms of Article $25 \mathrm{fa}$ of the Dutch Copyright Act, indicated by the "Taverne" license above, 


\section{Sexually Transmitted Infection and Chemsex Also Highly Prevalent Among Male Sex Workers Outside Amsterdam, The Netherlands}

$\mathrm{M}$ ale sex workers who have sex with men (MSW) are a high-risk group for acquiring sexually transmitted infections (STI) including human immunodeficiency virus (HIV). ${ }^{1}$ Substance use among MSW is associated with higher-risk sexual practices. ${ }^{1}$ Studies conducted inside and outside of the highly urban Amsterdam region have already presented high rates $(17.6 \%$ up to $34.8 \%$ ) of chemsex (intentionally using substances before or during sex) among men who have sex with men (MSM)., ${ }^{2,3}$

We have read the article by Drückler et $\mathrm{al}^{4}{ }^{4}$ with great interest. It described STI positivity, substance use, and chemsex among MSW in Amsterdam, the Netherlands. We would like to raise attention to the findings that STI and chemsex in MSW is also prevalent outside the highly urban Amsterdam region.

In a previously conducted study (2015) among $119 \mathrm{MSW}$ in the less urbanized region of South Limburg we presented an STI positivity rate of $40 \%$ and $8 \%$ newly found HIV infections. ${ }^{5}$ Comparably, Drückler et al. ${ }^{4}$ found a bacterial STI positivity rate of $31.3 \%$ and new HIV-infections in 6.1\% among $99 \mathrm{MSW}$.

In another, more recent study we have looked at chemsex among a large group of MSM, including $37 \mathrm{MSW}$, who visited public health service's STI clinics in nine regions in the Netherlands. ${ }^{6}$ We conducted a subanalysis of this data $(n=558)$ to review chemsex among MSW. Chemsex is defined by us in a broader definition: using cocaine, crystal meth, designer drugs, gamma-Hydroxybutyric acid (GHB)/gamma-Butyrolactone (GBL), ketamine, speed, or Ecstasy (XTC)/ methylenedioxymethamphetamine(MDMA) during sex in the past 6 months. In our study $48.6 \%$ (18/37) of MSW had chemsex, comparing to $40.5 \%(28 / 69)$ in Drückler et al. (using same chemsex definition without designer drugs). ${ }^{4}$ The percentage in our study mainly reflects the use of $\mathrm{GHB} / \mathrm{GBL}$ $(29.7 \%$; 11/37), followed by XTC/MDMA (27\%; 10/37). The STI positivity rate among MSW who had chemsex was $11.8 \%(2 / 17)$ in our study, whereas Drückler et al. ${ }^{4}$ found an STI positivity rate of $23.8 \%(5 / 28)$ among this group.

When using the more limited classic UK chemsex definition used by Drückler et al. (use of mephedrone, GHB/GBL or methylamphetamine before or during sex) $29.7 \%(11 / 37)$ in our study had chemsex, compared with $17.4 \%$ in the Amsterdam region. ${ }^{4}$ This percentage mainly reflects the use of GHB/GBL $(29.7 \%$; 11/37) followed by crystal meth $(10.8 \% ; 4 / 37)$ and mephedrone $(0 \%)$. This confirms our research group's view that $\mathrm{GHB} / \mathrm{GBL}$ is one of the most commonly used chemsex substances among MSM outside of Amsterdam. ${ }^{3}$ A respondent of a qualitative study we conducted among $20 \mathrm{MSW}$ in the province of Limburg confirmed common GHB/GBL use: "GHB is a requirement during sex. I think so, eh it is, GHB is, so to speak, a sex drug."

In conclusion, both STI positivity and chemsex rates are not only high among MSW inside but also outside of the highly urban Amsterdam region. This suggests the need for a nationwide public health approach for chemsex in MSW. Nevertheless, most MSW remain hidden to care for STI and chemsex consequently arguing for better reach.

Charlotte M.M. Peters, MS Ymke J. Evers, MSc

Nicole H.T.M. Dukers-Muijrers, MD Christian J.P.A. Hoebe, MD Department of Sexual Health Infectious Diseases and Environmental Health South Limburg Public Health Service
Heerlen, Limburg

The Netherlands

Department of Social Medicine and

Medical Microbiology

Care and Public Health Research Institute (CAPHRI)

Maastricht University/Maastricht UMC+

Maastricht, The Netherlands charlotte.peters@ggdzl.nl

The authors have no conflicts of interest to declare. The authors have received no specific funding for this work.

\section{REFERENCES}

1. Baral SD, Friedman MR, Geibel S, et al. Male sex workers: Practices, contexts, and vulnerabilities for HIV acquisition and transmission. Lancet 2015; 385:260-273.

2. Drückler S, van Rooijen MS, de Vries HJ. Chemsex among men who have sex with men: A sexualized drug use survey among clients of the sexually transmitted infection outpatient clinic and users of a gay dating app in Amsterdam, the Netherlands. Sex Transm Dis 2018; 45:325-331.

3. Evers YJ, Van Liere GAFS, Hoebe CJPA, et al. Chemsex among men who have sex with men living outside major cities and associations with sexually transmitted infections: A cross-sectional study in the Netherlands. PloS one 2019; 14:e216732.

4. Drückler S, van Rooijen MS, de Vries HJC. Substance use and sexual risk behavior among male and transgender women sex workers at the prostitution outreach center in Amsterdam, the Netherlands. Sex Transm Dis 2020; 47:114-121.

5. Verhaegh-Haasnoot A, Dukers-Muijrers NH, Hoebe CJ. High burden of STI and HIV in male sex workers working as internet escorts for men in an observational study: A hidden key population compared with female sex workers and other men who have sex with men. BMC Infect Dis 2015; 15:291.

6. Evers YJ, Hoebe CJPA, Dukers-Muijrers NHTM, et al. Sexual, addiction and mental health care needs among men who have sex with men practicing chemsex - A cross-sectional study in the Netherlands. Prev Med Rep 2020; 18:101074. 